\title{
Identification of Cryptosporidium sp. with the Microscopic Examination Method on HIV/AIDS Patients in Padang, West Sumatra
}

\author{
Nuzulia Irawati $^{1 *}$, Nora Harminarti ${ }^{1}$, A. K. Munzi Yulianto ${ }^{1}$ and Kemala Sayuti ${ }^{2}$ \\ ${ }^{1}$ Departement of Parasitology, Faculty of Medicine, Andalas University, \\ Padang, 25127, Indonesia \\ ${ }^{2}$ The eye part of the hospital is in M Djamil Padang, Padang, 25127, Indonesia \\ *Corresponding author
}

\section{Keywords \\ Zoonotic disease, Cryptosporidium, waterborne disease, parasites}

\section{Article Info}

Accepted: 15 September 2021 Available Online: 10 October 2021
Cryptosporidiosis is a zoonosis disease which classified as waterborne disease caused by Cryptosporidium sp. and can inflict acute to chronic diarrhea through small intestine infection. The basic in diagnosing cryptosporodiosis is microscopic or moleculer inspection of feces samples. The objective of this study was to find out the Cryptosporidium sp. infection in HIV/AIDS patients with cluster of differentiation 4 (CD4) $\leq 350 \mathrm{sel} / \mathrm{mm} 3$ in $\mathrm{m}$ djamil padang. This study was observational descriptive research by using feces, questionnaires, and medical record. This research samples were part of the population which fulfill in the inclusion and exclusion criteria in VCT Policlinic of $\mathrm{m}$ djamil padang. Two from forty respondences of this study was found positive of Cryptosporidium sp. Oocyst in their feces. The frequencies based on gender could not be determined because the different number of men and women respondences. From the anamnesis by using questionnaires, this two respondences with positive result did not have diarrhea (asymptomatic). Based on data on drinking water sources and daily water sources as a risk for Cryptosporidium sp infection, there were no significant numbers. From the same typed of water sources, more was found to be negative oocyst than positive oocyst. Based on the source of their drinking water, one of the used cooked water and the other one used retail refill water. Based on their daily water resources, both of them using Water Supply Company (PDAM). It could be influenced by the location, environmental factors, and activities of each of them those were different.

\section{Introduction}

Cryptosporidiosis is a zoonotic disease belonging to the waterborne disease. This disease is caused by parasites of the genus Cryptosporidium which are pathogenic organisms and are obligate intracellular. Cryptosporidium sp. can cause acute diarrhea 
in humans or animals by infecting the small intestine (Wijayanti, 2017).

The first time the discovery of parasitic infection Cryptosporidium sp. In humans, in 1976, infection occurred in a 3-year-old child who suffered from self-limiting enterocolitis.(Meisel, et al., 1976). In 1982, the first case of cryptosporidiosis was reported in a homosexual man with AIDS (Acquired Immune Deficiency Syndrome).(Ma P, 1983)Since then, many case reports in the world have identified that Cryptosporidium sp. become a significant pathogen for people living with HIV/AIDS (Iqbal, et al., 2012).

HIV (Human Immunodeficiency virus) is a virus that infects white blood cells in the body and causes a decrease in the patient's immune status (World Health Organization., 2004). According to data from UNAIDS (United Nations Program on HIV/AIDS) there is an increase in HIV/AIDS cases in the world. In 2010 there were around 30.9 million - 36.1 million cases (an average of 33.3 million) and in 2015 it was found around 34 million -39.8 million cases (an average of 36.7 million). The incidence of HIV/AIDS in the Asia Pacific region was recorded in 2010 as many as 4.7 million cases and in 2015 as many as 5.1 million cases (United Programme on HIV and AIDs, 2016).

The epidemiology of HIV/AIDS in Indonesia is also increasing every year. It was recorded that until December 2017 the total incidence of HIV was 280,623 cases and AIDS was 102,667 cases. In 2017 it was reported that there were 48,300 new cases of HIV and 9,280 new cases of AIDS. From these data, it was found that the highest percentage occurred in the age group of 25-49 years for the incidence of HIV and the age group of 30-39 years for the incidence of AIDS. For reports of cases of HIV infection by the Directorate General of Disease Prevention and Control (Dijen P2P) in
West Sumatra in 2017 there were 563 cases and AIDS as many as 267 cases (Direktoran Jenderal Pencegahan dan Pengendalian Penyakit (Ditjen, 2018).

Besides being caused by the lifestyle of modern humans who are susceptible to HIV infection, the increase in cases of HIV/AIDS also occurs because until now there is no definitive therapy to treat HIV. This causes transmission of transmission both vertically and horizontally to still occur. Currently available drugs only inhibit the process of HIV replication in the human body. The drug used is ART (Anti Retroviral Therapy) which is a combination of three drugs (United Programme on HIV and AIDs, 2016).

ODHA (People with HIV / AIDS) experience a decrease in immune status due to HIV infection which destroys CD4 $\mathrm{T}$ cells in the body. Therefore, people living with HIV are susceptible to opportunistic infections that can increase the potential for morbidity and mortality. The prevalence of opportunistic infections in HIV/AIDS patients varies from country to country (Shahapur PR, 2014). In Indonesia, according to the Ministry of Health of the Republic of Indonesia, the highest proportion of opportunistic infections is tuberculosis, chronic diarrhea, oropharyngeal candidiasis, generalized dermatitis, and persistent generalized lymphadenopathy (Kementerian Kesehatan Republik Indonesia., 2010). Therefore, WHO (World Health Organization) recommends starting ART treatment for all HIV patients with CD4 350 cells $/ \mathrm{mm}^{3}$ because based on research this can inhibit progression to AIDS (World Health Organization (WHO, 2016).

Cryptosporidium sp. is one of the causes of chronic diarrhea in HIV/AIDS patients (Center for Disease Control and Prevention., 2018). Transmission of this protozoa occurs by faecal-oral route. There are various risk 
factors for Cryptosporidium sp infection. such as food and drink contaminated with oocysts, poor hygiene, direct or indirect contact with infected animals, and human-to-human infections in homes or health services (Rossle, 2013).

Information regarding the incidence of cryptosporidiosis in Indonesia is still very limited. According to the data obtained, the incidence in the United States, Canada, and Europe ranges from 1-5\%, in Asia 4.9\% and Africa 10.4\% (Wijayanti, 2017). In the examination conducted on 318 stool samples of HIV patients with symptoms of diarrhea in the period November From 2004 to March 2007 at the Department of Parasitology, Faculty of Medicine, University of Indonesia, Cryptopsporidium sp. as the second most common parasite after Blastocytis hominis, which is $11.9 \%$ (Wahdini and Kurniawan, 2016). In 2017 a study was conducted by Handayani SW regarding Cryptosporidium sp. in HIV/AIDS patients at Dr. M. Djamil Padang regarding the relationship between CD4 cell count and Cryptosporidium sp. (diarrhea/non-diarrhea). Through microscopic examination, 22 out of 42 (52.38\%) samples detected Cryptosporidium sp. oocysts. From this study, it was also found that the tendency for infection to occur is directly proportional to the lower CD4 count (Handayani, 2017).

In immunocompetent patients, infection is confined to the ileal area. However, in severely immunocompromised patients, the infection can spread along the gastrointestinal tract, large intestine, proximal gastrointestinal tract (gastric and oesophageal mucosa) and can also infect the respiratory tract (World Health Organization (WHO, 2006). In a study in Spain mentioned, 7 of 43 patients with AIDS (16.3\%) with chronic diarrhea due to infection with Cryptosporidium sp. oocysts were detected in the sputum (Hunter, 2002). Cryptosporidiosis in HIV patients can cause severe and prolonged diarrhea, especially in patients with a low CD4 T cell count of $<200$ cells $/ \mathrm{mm}^{3}$, whereas in patients with a higher CD4 T cell count of $>200$ cells $/ \mathrm{mm}^{3}$, diarrhea is mild or moderate. asymptomatic and healing can occur spontaneously (self limiting) (Iqbal et al., 2012).

A study conducted on immigrants, military personnel, and travelers in India with a sample of 45 and HIV positive, found that $80 \%$ had no symptoms of diarrhea (asymptomatic) and $20 \%$ showed symptoms of diarrhea (symptomatic). In this study, $80 \%$ of asymptomatic patients found oocysts of Cryptosporidium sp. on stool samples examined by microscopic examination and ELISA (Masarat et al., 2012).

Until now there is no specific treatment for Cryptosporidium sp. in HIV/AIDS patients. In HIV infection the number of CD4 T lymphocytes which are components of the cells in the lamina propria will decrease. (Wahdini, 2010) A study showed that CD4 T cells have an important role in the immune process in response to the infection process of Cryptosporidium sp. Several studies say the use of HAART (highly active antiretroviral therapy) in the treatment of HIV infection, shows changes in the health status of AIDS patients in the process of healing from cryptosporidiosis (Iqbal et al., 2012).

Diagnosis of Cryptosporidium sp. can be confirmed by microscopic examination and molecular examination. Molecular assays have high sensitivity and specificity, but require expensive reagents. So that in Indonesia in the examination of Cryptosporidium sp. more microscopically. Although it has lower sensitivity and specificity than molecular examination, microscopic examination requires simpler and relatively inexpensive equipment so that it is more possible in mass examination (Wijayanti, 2017). 
Along with the increase in HIV/AIDS cases in Indonesia and chronic diarrhea as one of the most common opportunistic infections, the incidence of Cryptosporidium sp. need attention. At RSUP Dr. M. Djamil Padang there is no routine examination of Cryptosporidium sp. in HIV/AIDS patients, as evidenced by no data regarding the number of infections caused by this parasite. Therefore, researchers are encouraged to identify Cryptosporidium sp. with the method of microscopic examination of HIV/AIDS patients at Dr. M. Djamil Padang.

\section{Materials and Methods}

This type of research is a descriptive study, namely by directly examining stool samples from HIV/AIDS patients. This type of research is observational conducted on HIV/AIDS sufferers at Dr. M. Djamil Padang. This research is part of the research conducted by the lecturer with the title "Identification and Detection of Cryptosporidium sp. on HIV/AIDS sufferers at Dr. M. Djamil Padang". In this study, the sample size was 40 plus $10 \%$ to avoid dropping out to 44 .

The population of this study is all HIV/AIDS patients who have been clinically proven from the laboratory of Dr. RSUP. M. Djamil Padang.

The sample of this study was part of the population that met the inclusion criteria and did not have the exclusion criteria at the VCT Polyclinic of Dr. RSUP. M. Djamil Padang. Inclusion criteria: all HIV-infected patients with positive results (+) with CD4 count 350 cells/mm3 and willing to become respondents by signing informed consent. Exclusion criteria: patients with HIV/AIDS with chronic diarrhea who are receiving antiparasitics.

After the prospective respondent is given an explanation about the research to be carried out and signed the informed consent, the respondent will fill out personal data and questionnaires in the form of being experiencing diarrhea/not having diarrhea, having a history of diarrhea/not, drinking water sources, and clean water sources. Then the respondent will be given a sample pot to collect their faeces in the morning and take it to the VCR Polyclinic of Dr. RSUP. M. Djamil Padang. Furthermore, the sample will be taken to the Parasitology Laboratory of the Faculty of Medicine, Andalas University for a modified Ziehl Neelsen acid-fast stain and examined using a microscope.

\section{Results and Discussion}

The study was conducted on 44 HIV/AIDS patients who were at the VCT Polyclinic, Dr. M. Djamil Padang. During the research process, the number of patients who met the criteria were 40 people.

Based on table 1 , out of 40 people who were respondents, it was found that there were four people with diarrhea and 36 non-diarrhea. Two of the 36 non-diarrhea were identified as positive for Cryptosporidium sp. Oocysts.

Based on table 2, it can be seen that the proportion of respondents infected with Cryptosporidium sp. by gender. One of the 30 males tested positive and one of the ten females tested positive. Based on table 3, the source of drinking water used by oocystpositive respondents was boiled water with an incidence of one in 13 and retail refill drinking water with an incidence of one in 21 . While users of branded refilled drinking water were not identified with Cryptosporidium sp. oocysts.

Based on table 4, 19 respondents used PDAM as their daily water source and 21 respondents used wells. Two of the 19 PDAM users were identified as positive for Cryptosporidium sp. oocysts. 
Based on table 1, it was found that two of the 40 faecal samples were identified as positive for Cryptosporidium sp. In terms of the proportion of events in this study, only 5\% were positive, not as high as in the previous year which was also carried out at the same location by Handayani SW (2017) which was found to be $52.38 \%$ (22/42). (Handayani SW., 2017)This can be caused by lifestyle changes, especially in avoiding risk factors for Cryptosporidium sp oocyst infection. that have been suggested to patients based on previous research. In addition, there are also differences in criteria, Handayani (2017) uses the CD4 criteria 200 cells $/ \mathrm{mm}^{3}$. (World Health Organization (WHO)., 2006) Patients with CD4 values 200 cells $/ \mathrm{mm}^{3}$ are more susceptible to infection and are also more difficult to heal and eliminate from Cryptosporidium sp oocysts. (Iqbal, et al., 2012).

The two patients who were identified as positive did not show clinical symptoms of diarrhea (asymptomatic). This is in line with the research conducted by Masarat et al., (2012) on immigrants, army personnel, and travelers in India where HIV/AIDS patients infected with Cryptosporidium sp. also may not show symptoms of diarrhea (asymptomatic). (Masarat S, Ahmad F, Chisti M, Hamid S, 2012) Based on the anamnesis of the two patients who were identified as routinely positive for taking ARVs. This affects the possibility of symptoms or not. Because in the process of healing from infection with Cryptosporidium sp. for HIV/AIDS patients, it is very dependent on the increase in the number of CD4 $\mathrm{T}$ cells.
(Iqbal, et al., 2012). There are four respondents who experienced symptoms of diarrhea but no Cryptosporidium sp oocysts were found. on inspection. This may be due to the cause of diarrhea not Cryptospordium sp. or infected but no oocysts were found in the preparation due to the small number of oocysts.

In table 2, it can be seen that there are differences in the number of male and female respondents, so that the comparison of the frequency of occurrence between men and women cannot be determined. There is no specific correlation for the incidence of cryptosporidiosis with certain sexes. Based on several studies in different locations, it was found that the proportion of the incidence of infection varied. The study conducted by Hamad MNM (2018) was obtained from the study population with $50.8 \%$ female infected and $27.3 \%$ male (Hamad, 2018).

While the study conducted by Adamu et al., (2014), found the incidence of infection in men $29.7 \%$ and women $23.7 \%$. (Adamu, et al., 2014) However, in a study conducted in Europe and America there were differences in the risk factors for cryptosporidiosis based on the mode of HIV infection. The incidence of cryptosporidiosis was significantly lower for injecting needle users than for homosexual men. This raises speculation about sexual behavior having an important role in the incidence of cryptosporidiosis, so that men, especially homosexuals, are more susceptible to infection with Cryptosporidium sp. than women'(Hunter, 2002) 
Table.1 Proportion of HIV/AIDS sufferers with CD4 350 cells/mm3 at Dr. RSUP. M. Djamil Padang infected with Cryptosporidium sp. based on symptoms of diarrhea

\begin{tabular}{|c|c|c|c|c|}
\hline $\begin{array}{c}\text { Inspection } \\
\text { Cryptosporidium sp }\end{array}$ & $\begin{array}{c}\text { Clinical symptoms } \\
\text { Diarrhea }\end{array}$ & Non- diarrhea & f & \% \\
\hline Ookista (+) & 0 & 2 & 2 & 5 \\
Ookista (-) & 4 & 34 & 38 & 95 \\
Total & 4 & 36 & 40 & 100 \\
\hline
\end{tabular}

Table.2 Proportion of HIV/AIDS sufferers with CD4 350 cells/mm3 at Dr. RSUP. M. Djamil Padang infected with Cryptosporidium sp. by gender

\begin{tabular}{|c|c|c|c|c|}
\hline Inspection & Clinical symptoms & Non- diarrhea & & f \\
Cryptosporidium sp & Diarrhea & & 2 & \% \\
\hline Ookista (+) & 1 & 1 & 38 & 5 \\
Ookista (-) & 29 & 9 & 40 & 95 \\
Total & 301 & 10 & 100 \\
\hline
\end{tabular}

Table.3 Proportion of HIV/AIDS sufferers with CD4 350 cells/mm3 at Dr. RSUP. M. Djamil Padang infected with Cryptosporidium sp. based on drinking water sources.

\begin{tabular}{|c|c|c|c|c|}
\hline Source of mineral water & \multicolumn{2}{|c|}{$\begin{array}{c}\text { Inspection } \\
\text { Cryptosporidium sp } \\
\text { Ookista (+) Ookista (-) }\end{array}$} & f & \% \\
\hline Boiled water & 1 & 12 & 13 & 32,5 \\
Uncooked water & 0 & 0 & 0 & 0 \\
Retail refill drinking water & 1 & 20 & 21 & 52,5 \\
Branded refill drinking water & 0 & 6 & 6 & 15 \\
Total & 2 & 38 & 40 & 100 \\
\hline
\end{tabular}

Table.4 Proportion of HIV/AIDS patients with CD4 350 cells/mm3 at Dr. M. Djamil Padang infected with Cryptosporidium sp. based on daily water sources

\begin{tabular}{|c|c|c|c|c|}
\hline Daily source of water & $\begin{array}{c}\text { Inspection } \\
\text { Cryptosporidium sp } \\
\text { Ookista (+) }\end{array}$ & Ookista (-) & f & \% \\
\hline PDAM & 2 & 17 & 19 & 47,5 \\
Well & 0 & 21 & 21 & 52,5 \\
River & 0 & 0 & 0 & 0 \\
Total & 2 & 38 & 40 & 100 \\
\hline
\end{tabular}

The results of the identification of drinking water sources and daily water sources did not show significant numbers in looking at risk factors for Cryptosporidium sp. In numbers, only one in 13 users of boiled drinking water were identified as positive, one in 21 retail 
refilled drinking water was identified as positive, and 6 respondents tested negative for branded refilled drinking water. However, this is in line with the research conducted by Handayani SW (2017) where there were respondents who were identified as positive using boiled drinking water and refilled drinking water (Handayani, 2017). However, the low incidence based on drinking water sources in this study could be caused by differences in location. the purchase of retail refill drinking water, it depends on the maintenance of the equipment, the hygiene of the officers/operators, and the condition of the drinking water depot for contamination of drinking water. As for one person who is infected even though using boiled drinking water, it may be affected by the length of cooking or the cleanliness of the water source.The CDC recommends that boiled water must first go through a reverse osmosis filter, with an absolute size of 1 micron or a filter certified to remove Cryptosporidium under NSF International Standard 53 to remove or reduce oocysts in water. After that, the water must be boiled and allowed to boil for 1 minute (Working Group on Waterborne Cryptosporidiosis (WGWC, 1997) According to WHO, Cryptosporidium parvum oocysts will be inactive when the water temperature has reached $70^{\circ} \mathrm{C}$ (World Health Organization (WHO, 2011)

For PDAM's daily water sources, two out of 19 were identified as positive and 21 respondents tested negative for well users. Two PDAM users can be infected through PDAM water or not, to make sure the PDAM water needs to be checked, because the use of PDAM is mass, if it is proven that there are oocysts in the PDAM water, it is necessary to evaluate and purify it because it can cause an epidemic. For well water users, no one was infected, this could be due to the hygiene of the well water which is maintained by closing the well to avoid animals. Based on the history taken for the two positive patients, in terms of hygiene, both of them only washed their hands with water without soap, it became one of the risk factors for the entry of oocysts when eating with hands. In the home environment of the two positive respondents, there are also wild animals, namely cats that may contaminate drinking water or food consumed by these respondents'(Cacciò, 2014)There are several different possibilities that are risk factors for Cryptosporidium sp infection. on respondents such as different residential locations, personal hygiene, environmental risk factors (wild animals and environmental hygiene) and different activities.

Based on the results of this study, it was concluded that two of the 40 respondents who were HIV/AIDS patients at RSUP Dr. M. Djamil Padang identified Cryptosporidium sp. oocysts. in his faeces. Two respondents who tested positive did not show symptoms of diarrhea (asymptomatic). Of the 2 respondents who tested positive, 1 was male and 1 was female.

However, there are differences in the number of respondents from each gender, so the prevalence by sex cannot be determined. Based on data on drinking water sources and daily water sources as a risk factor for infection with Cryptosporidium sp oocysts. obtained through the questionnaire there are no significant figures. Because of the same type of drinking water source and daily water source, more negative oocyst respondents were found than positive. This can be influenced by different locations, environmental factors, and activities of each respondent.

\section{Recommendations}

Based on the conclusions above, it is hoped that further investigation of risk factors for the occurrence of cryptosporidiosis in HIV/AIDS 
patients is expected because the number of HIV/AIDS sufferers in West Sumatra is always increasing.

\section{Acknowledgments}

The researcher would like to thank all those who have helped in completing this research.

\section{References}

Adamu H, Petros B, Zhang G, Kassa H, Amer $\mathrm{S}$, Ye J, et al., Distribution and clinical manifestations of Cryptosporidium species and subtypes in HIV/AIDS patients in Ethiopia. PLOS Negl Trop Dis. 2014;8(4):1-10.

Cacciò S M, Widmer G. Cryptosporidium: Parasite and Disease. Springer-Verlag Wien. Italia. 2014:1- 564.

Center for Disease Control and Prevention. AIDS and Opportunistic Infections. U.S. Department of Health \& Human Services. 2018.

Direktoran Jenderal Pencegahan dan Pengendalian Penyakit (Ditjen P2P). Laporan Situasi Perkembangan HIVAIDS \& PIMS di Indonesia Januari Desember 2017. Kementerian Kesehatan Republik Indonesia. 2018

Hamad M N M. Prevalence of cryptosporidiosis among selected group of sundanese patients. Advancements Bioequiv Availab. 2018;1(5):1-4.

Handayani S W. Hubungan Jumlah Sel CD4 dengan Infeksi Cryptosporidium sp. (diare/non-diare) pada Penderita HIV/AIDS di Rumah Sakit Dr. M. Djamil Padang [Tesis]. Fakultas Kedokteran Universitas Andalas. Padang. 2017.

Hunter P R, Nichols G. Epidemiology and Clinical Features of Cryptosporidium Infection in Immunicompromised Patients. Clin Microbiol Rev.
2002;15(1):145;154

Iqbal A, Lim Y A L, Mahdy M A K, Dixon B R, Surin J. Epidemiology of Cryptosporodiosis in HIV-Infected Individuals: A Global Perspective. Departmen of Parasitology, Faculty of Medicine, University of Malaya. 2012;1(9);1-15

Kementerian Kesehatan Republik Indonesia. Kasus AIDS Didominasi Usia Produktif. Pusat Komunikasi Publik, Sekretariat Jenderal Kementerian Kesehatan RI. 2010.

Ma P, Soave R. Three-step stool examination for cryptosporidiosis in 10 homosexual men with protracted watery diarrhea. J Infect Dis. 1983;147:824-828.

Masarat S, Ahmad F, Chisti M, Hamid S, Ahmad $\mathrm{S}$ B. Prevalence of Cryptosporidium species among HIV positive asymptomatic and symptomatic immigrant population in Kashmir, India. Iran J Microbiol. 2012;4(1):35-39

Meisel J L, Perera D R, Meligro C, Rubin C E. Overwhelming watery diarrhea associated with a Cryptosporidium in an immunosuppressed patient. Gastroenterology. 1976;70:1156-1160.

Rossle N F, Latif B. Cryptosporidiosis as threatening health problem: A review. Asian Pacific Journal of Tropical Biomedicine. 2013;3(11):916-924.

Shahapur P R, Bidri R C. Recent Trends in the spectrum of opportunistic infections in human immunodeficiency virus infected individuals on antiretroviral therapy in South India. J Nat Sci Biol Med. 2014 Jul-Dec;5(2):392-396.

United Programme on HIV and AIDS. Global AIDS Update 2016. Geneva:WHO. 2016;(March):422

Wahdini S, Kurniawan A, Yunihastuti E. Deteksi Koproantigen Cryptosporidium sp pada Pasien HIV/AIDS dengan Diare Kronis. eJKI. 
2016;4(1):49- 53.

Wahdini S, Kurniawan A. Respon Imun Pada Infeksi Cryptosporidium. Majalah Kedokteran FK UKI. 2010;27(3):130137.

Wijayanti T. Kriptosporodiosis di Indonesia. Balai Litbang Pengendali Penyakit Bersumber Binatang. 2017;13(1):7382.

Working Group on Waterborne Cryptosporidiosis (WGWC). Cryptosporidium and water: a public health handbook 1997. CDC. 1997.

World Health Organization (WHO). 4 Clinical
Guidelines: Antiretroviral Therapy. Consol Guidel Use Antiretrovir Drugs Treat Prev HIV Infect Recomm a Public Heal Approach. 2016; (2nd edition): 129

World Health Organization (WHO). Boil Water. WHO. 2011.

World Health Organization (WHO). Cryptosporidium, WHO Guidelines for Drinking Water. WHO. 2006.

World Health Organization. Module 1 Introduction on HIV/AIDS. WHO. $2004 ; 1-22$

\section{How to cite this article:}

Nuzulia Irawati, Nora Harminarti, A. K. Munzi Yulianto and Kemala Sayuti. 2021. Identification of Cryptosporidium sp. with the Microscopic Examination Method on HIV/AIDS Patients in Padang, West Sumatra. Int.J.Curr.Microbiol.App.Sci. 10(10): 402-410. doi: https://doi.org/10.20546/ijcmas.2021.1010.048 